\title{
The economic argument for hiring people with disabilities
}

Thomas Aichner (iD ${ }^{1 凶}$

The question of whether people with disabilities should be hired as employees can be considered from three different perspectives: moral, legal, and economic. From a moral point of view, the question can clearly be answered in the affirmative. After all, respect and charity are among the most important cultural and religious values of our society. If a company does not face up to this moral obligation, the company's image suffers and there may be social consequences that can result in negative word-of-mouth and lower sales. The legal situation differs between countries but is usually relatively simple and straightforward. In Italy, for example, companies with 15 to 35 employees must employ one person with a disability. For larger companies with 36 to 50 employees, this figure rises to two and with more than 51 employees, a total of $7 \%$ of all employees must be disabled. If a company does not comply with this quota system, fines will be imposed. This article deals with the third aspect, which for many companies is most important: the economic one. The central question is whether and under what conditions an employee with a disability can perform just as well or even better than a non-disabled colleague and therefore contribute to the economic success of a business. With a number of examples from research and practice, it is illustrated that economic reasons-in addition to moral arguments and legal obligations-also speak in favor of hiring disabled employees.

\footnotetext{
${ }^{1}$ Department of Business Administration, John Cabot University, Rome, Italy. ${ }^{凶}$ email: mail@thomasaichner.eu
} 


\section{Introduction}

1 hen it comes to finding appropriate jobs, people with disabilities are still heavily disadvantaged. This is mainly because of negative prejudices of employers, which often believe that people with disabilities are not able to perform as efficiently as non-disabled workers, or that they are a burden rather than a source of added value to the company. These fixed patterns of thinking and unwelcome corporate cultures (Ali et al., 2011) prevail in most industries and across borders, having a significant impact on the lives of people with disabilities who are looking for a job or that are currently working. In both situations, the biased reasoning of managers and corporate decision makers leads to disadvantages not only for the jobseeker or employee, but also for the employer. Whether it is because companies are not hiring a person with a disability or because they are not fully using their employee's skills, they are missing out on important opportunities and ultimately hurting their firm's profitability and success.

This article's focus does not lie on the moral or legal obligation of companies to include people with disabilities, but on the economic aspects of employment that contribute to the success of a company. The results of countless studies speak for themselves: If the right people with disabilities are selected for the right job and are given responsibility, they often outperform other employees, with higher levels of efficiency, productivity, accurateness, commitment, loyalty, and satisfaction. This, in turn, increases the company's profitability and overall shareholder value. The key arguments are summarized in Fig. 1.

\section{People with disabilities are highly motivated to work}

The majority of people with disabilities wish to be engaged in some sort of meaningful activity (Boardman et al., 2003). For most people, this meaningful activity is a synonym for work as an employee. In fact, more than 50 studies exploring the meaning of work for people with cancer, mental illnesses, brain injuries, paraplegia, AIDS, and musculoskeletal disorders found that work continued to play a vital role in their lives, as it is perceived to be a source of identity, while providing feelings of normality, socialization, and financial support (Saunders and Nedelec, 2014). Although paid work is obviously an important source of income for families with a disabled family member, the major motivational drivers to continue working, despite a disability, are social integration and participation rather than of a financial nature
(Marti et al., 2012). Research also shows that motivational levels of employees with disabilities are not just comparable but significantly higher-than-average. One reason for this is that it is considerably more difficult for them to even get a job. Once hired, people with disabilities appreciate the opportunity to work and are more motivated to perform above what is expected. On the other hand, the higher motivation is also due to the fact that others, e.g., co-workers or managers, place less confidence in people with disabilities, who in turn want to convince their colleagues of the opposite. This higher level of motivation leads to better quality, friendlier dealings with customers, higher loyalty towards their employer, and more consistent performance.

Another key aspect of human resources management is employee satisfaction. A broad body of research suggests high job satisfaction in people with disabilities (Kocman and Weber, 2018), which generally leads to lower employee turnover and higher return on investments in training and development. Employees with disabilities work harder, are more productive, more loyal, and show lower absenteeism rates (Hernandez et al., 2008). For example, a participant in a study about employers' perceptions of their disabled workforce reported:

"[A disabled employee has] been with us for 35 years. He's never missed a day and he's never late. Whenever there's a snowstorm, he prepares to get to work on time and most of the time the manager's not there. So, we look at that individual and say, 'Wow! We need more guys like that." (Hernandez et al., 2008, p. 162)

\section{Advantages for companies hiring people with disabilities}

The authors of the same study (Hernandez et al., 2008) concluded that although costs associated with employing people with disabilities were minimal, and employing them helped create an overall more positive work environment, managers are still biased against hiring workers with disabilities. From a business perspective, these kinds of biases are very problematic, as it is the manager's duty to select people and manage operations in a way that maximizes profits and shareholder value. Excluding people with disabilities ex ante can therefore harm the economic performance of the firm, and ultimately place a business at risk for losing customers to its competitors. The following examples are

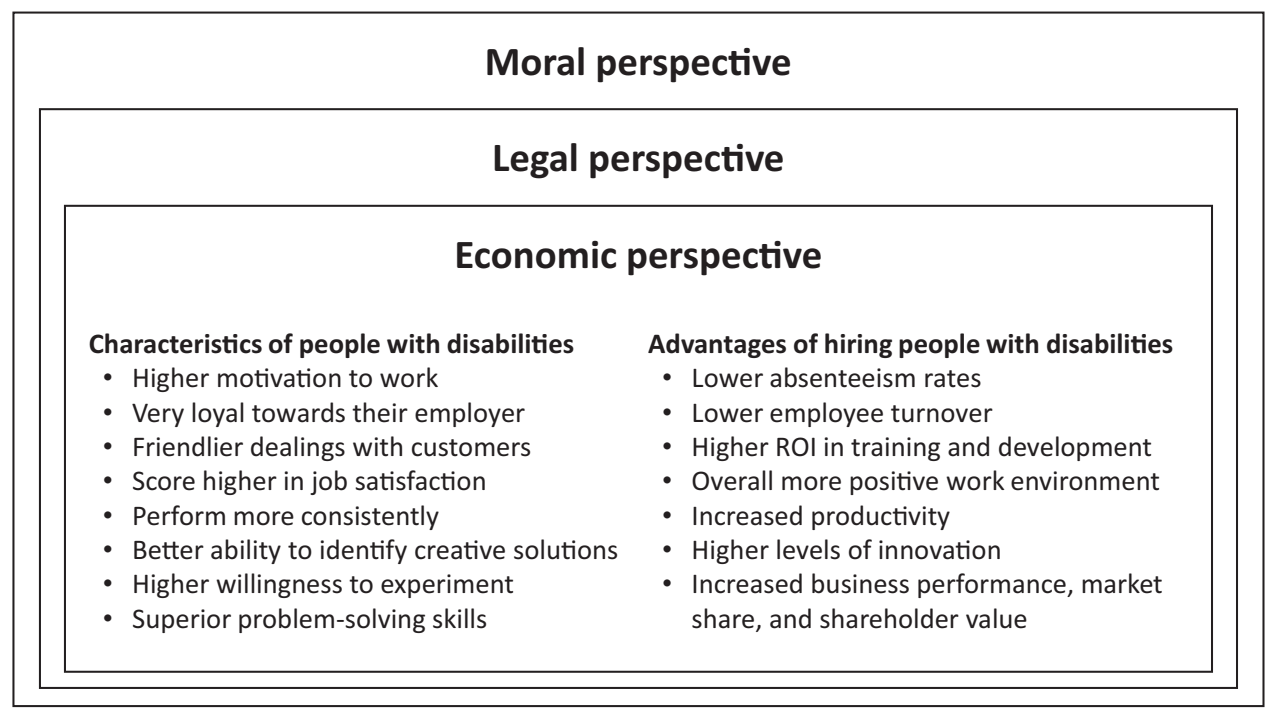

Fig. 1 Key economic arguments for hiring people with disabilities. 
meant to highlight best practices and to advocate disability inclusive hiring.

In 2007, the American company Walgreens opened a distribution center in which more than $30 \%$ of the 800 employees lived with a disability. The result was surprising, as the center was $20 \%$ more efficient than comparable facilities without disabled workers. In addition, employee turnover was half that of other employees, and people with disabilities had a third fewer incidents or accidents than their non-disabled colleagues (Kaletta et al., 2012). To successfully integrate and to take full advantage of the skills and capabilities of people with disabilities, it is often sufficient for the company to make small changes to the people's workplace or production process. This can be done, for example, by creating a little more space for a wheelchair user or by breaking a production step into two simpler individual operations. Besides changes of work tasks and physical adaptations of the workplace, it may also be enough to change working time (Kuznetsova and Cerdeira Bento, 2018).

People with intellectual disabilities often work more concentrated and accurately, which is why they perform repetitive tasks particularly well. One company that relies on this strength is the Asperger Informatik AG (Conza and Juric, 2013). The Swiss company prefers to employ people with Asperger's syndrome, a mild form of autism. People with Asperger's are often intellectually gifted, have a quick grasp, high attention to detail, extreme ability to concentrate, tenacity and perseverance. These are ideal conditions for a company working with information technology. In order to be able to use these special abilities, the company creates a low-irritation environment for its employees, minimizes stress and pressure, finds suitable task areas and plans the work processes as accurately as possible (Conza and Juric, 2013). Despite these advantages, applicants who mention their Asperger's syndrome when applying for an accounting position receive about 26\% fewer expressions of employer interest (Ameri et al., 2018). This percentage value is counter-intuitive and can only be explained by either a lack in knowledge by the hiring manager and/or a conscious or unconscious bias against people with disabilities.

Even severely handicapped people can contribute to the economic success of a company, if they are deployed correctly. Computer-assisted activities in particular can also be performed by blind people or people with severe motor disabilities. Since they are usually also dependent on technical products in their private lives, there is often an increased interest and an above-average understanding of technology and information technology. The increasingly frequent possibility of working from home also facilitates the integration of these people into the world of work. This is exactly what the more than 100-year-old American company Alphapointe-which offers manufacturing, assembly, and contract management-does. The company employs more than 120 blind employees, which make up more than $50 \%$ of the total workforce. According to an article published on July 23, 2017 on the New York Post website, Alphapointe's CEO confirms that "People who are blind are capable, productive, skilled and loyal employees when given the opportunity to prove themselves. Truly, hiring someone who's blind is the same as hiring someone who's sighted".

\section{Disadvantages for companies not hiring people with disabilities}

When a company decides not to employ people with disabilities, this can lead to a number of potential competitive disadvantages. Three key issues are missing out on employing individuals that are highly skilled, losing employees that could provide alternative approaches to problem-solving, and not being able to properly target customers with disabilities.

Average grades and graduation outcomes are mostly identical between students with disabilities and able-bodied students (Jorgensen et al., 2005). In many Western and industrialized countries where access to higher education is guaranteed and sometimes even incentivized for disadvantaged groups, large percentages of people with disabilities complete secondary or higher education. In Germany, for example, the relative percentage of people with disabilities that are considered to be qualified specialists is higher than amongst people without disabilities. Therefore, when a company's recruitment policies and practices are biased against hiring people with disabilities, they can miss the opportunity to employ highly skilled workers.

Secondly, people with disabilities are often more likely to find appropriate solutions to complex and unexpected problems. This is because they are coping with sometimes difficult personal situations in environments that are not always meant to accommodate their specific requirements. This necessity to adapt and to find solutions to problems and situations in life that non-disabled people do not face, equips people with disabilities with superior problem-solving skills (Lindsy et al., 2019) and higher willingness to experiment. Given that a company's ability to identify creative and innovative solutions can give it a competitive edge, not hiring people with these sought-after capabilities certainly poses a financial thread to businesses.

Thirdly, the number of customers with disabilities is increasing and becoming a more important target segment for many companies (Aichner and Shaltoni, 2018). According to the World Health Organization, about $15 \%$ of the world's population has some form of disability, which makes them significant when it comes to selling products and services. Having employees with disabilities being involved in product development and other strategic management and marketing functions certainly helps in better understanding customers with disabilities which constitute one seventh of the people living on the planet. Losing this opportunity may mean losing market share and can lead to lower returns.

A study including 140 U.S. companies confirms that disability inclusion efforts increase business performance, specifically innovation, shareholder value, productivity, and market share (Accenture et al., 2018). Comparing so-called "disability inclusion champions" with companies that score lower in their efforts to hire and include people with disabilities, revenue of companies hiring disabled employees is $28 \%$ higher, economic profit margins are $30 \%$ higher, and net income is $111 \%$ higher.

\section{Conclusions}

Employment rates of people with disabilities are lower than average, while their motivation to work is generally high. The combination of these two pieces of information alone would suggest that companies should be willing to hire people with disabilities. In addition, previous research shows that people with disabilities score higher in a number of efficiency-related metrics and assessments and not hiring disabled employees can mean companies are missing out on opportunities to increase productivity and economic success.

So why are so many people with disabilities still unemployed even though they are of working age? A reason why commitment to disability inclusive hiring is limited may be low employer knowledge, especially at the HR and management levels (Saleh and Bruyère, 2018), as well as social barriers resulting from a lack of social support (Naraine and Lindsay, 2011). If more companies recognize the potential of disabled workers and manage to recruit the right person for the right job, everyone could benefit. The 
Asperger Informatik AG calls it a win-win-win situation for the economy, society, and the individual.

Received: 17 October 2020; Accepted: 16 December 2020;

Published online: 22 January 2021

\section{References}

Accenture, Disability: IN, The American Association of People with Disabilities (2018) Getting to Equal: The Disability Inclusion Advantage. https://www. accenture.com/_acnmedia/PDF-89/Accenture-Disability-Inclusion-ResearchReport.pdf. Accessed 24 Nov 2020

Aichner T, Shaltoni AM (2018) Marketing of specialised products and services to consumers with disabilities: exploring the role of advertising, countryof-origin, and e-commerce. Int Rev Retail Distribut Consumer Res 28 (2):115-136. https://doi.org/10.1080/09593969.2017.1364658

Ali M, Schur L, Blanck P (2011) What types of jobs do people with disabilities want? J Occupat Rehab 21(2):199-210. https://doi.org/10.1007/s10926-0109266-0

Ameri M, Schur L, Adya M, Bentley FS, McKay P, Kruse D (2018) The disability employment puzzle: a field experiment on employer hiring behavior. ILR Rev 71(2):329-364. https://doi.org/10.1177/0019793917717474

Boardman J, Grove B, Perkins R, Shepherd G (2003) Work and employment for people with psychiatric disabilities. Br J Psychiatry 182(6):467-468. https:// doi.org/10.1192/bjp.182.6.467

Conza S, Juric I (2013) Mitarbeiter mit Asperger-Syndrom in der Informatikbranche-das Konzept der Asperger Informatik AG. Zürich. In: Böhm S, Baumgärtner M, Dwertmann D (eds) Berufliche Inklusion von Menschen mit Behinderung. Springer Gabler, Berlin, pp. 101-111

Hernandez B, McDonald K, Divilbiss M, Horin E, Velcoff J, Donoso O (2008) Reflections from employers on the disabled workforce: focus groups with healthcare, hospitality and retail administrators. Employee Responsib Rights J 20(3):157-164. https://doi.org/10.1007/s10672-008-9063-5

Jorgensen S, Fichten CS, Havel A, Lamb D, James C, Barile M (2005) Academic performance of college students with and without disabilities: an archival study. Canadian Journal of Counselling 39(2):101-117

Kaletta JP, Binks DJ, Robinson R (2012) Creating an inclusive workplace: integrating employees with disabilities into a distribution center environment. Professional Safety 57(6):62-71

Kocman A, Weber G (2018) Job satisfaction, quality of work life and work motivation in employees with intellectual disability: a systematic review. J Appl Res Intellect Disabilities 31(1):1-22. https://doi.org/10.1111/ jar.12319

Kuznetsova Y, Cerdeira Bento JP (2018) Workplace adaptations promoting the inclusion of persons with disabilities in mainstream employment: a casestudy on employers' responses in Norway. Soc Inclusion 6(2):34-45. https:// doi.org/10.17645/si.v6i2.1332
Lindsay S, Cagliostro E, Leck J, Shen W, Stinson J (2019) Disability disclosure and workplace accommodations among youth with disabilities. Disability Rehab 41(16):1914-1924

Marti A, Reinhardt JD, Graf S, Escorpizo R, Post MWM (2012) To work or not to work: labour market participation of people with spinal cord injury living in Switzerland. Spinal Cord 50:521-526. https://doi.org/10.1038/sc.2011.181

Naraine MD, Lindsay PH (2011) Social inclusion of employees who are blind or low vision. Disability Soc 26(4):389-403. https://doi.org/10.1080/ 09687599.2011.567790

Saleh MC, Bruyère SM (2018) Leveraging employer practices in global regulatory frameworks to improve employment outcomes for people with disabilities. Soc Inclusion 6(1):18-28. https://doi.org/10.17645/si.v6i1.1201

Saunders SL, Nedelec B (2014) What work means to people with work disability: a scoping review. J Occupat Rehab 24(1):100-110. https://doi.org/10.1007/ s10926-013-9436-y

\section{Competing interests}

The author is the president of the Association for Invalid Civilians (ANMIC South Tyrol), a non-profit organisation headquartered in Bolzano, South Tyrol, Italy. ANMIC South Tyrol is a branch of the Italian National Association for Disabled and Invalid Civilians (ANMIC), which is the only legally recognised advocacy for invalid civilians under Italian state law. There are no other conflicts of interest.

\section{Additional information}

Correspondence and requests for materials should be addressed to T.A.

Reprints and permission information is available at http://www.nature.com/reprints

Publisher's note Springer Nature remains neutral with regard to jurisdictional claims in published maps and institutional affiliations.

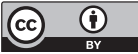

Open Access This article is licensed under a Creative Commons Attribution 4.0 International License, which permits use, sharing, adaptation, distribution and reproduction in any medium or format, as long as you give appropriate credit to the original author(s) and the source, provide a link to the Creative Commons license, and indicate if changes were made. The images or other third party material in this article are included in the article's Creative Commons license, unless indicated otherwise in a credit line to the material. If material is not included in the article's Creative Commons license and your intended use is not permitted by statutory regulation or exceeds the permitted use, you will need to obtain permission directly from the copyright holder. To view a copy of this license, visit http://creativecommons.org/ licenses/by/4.0/.

(C) The Author(s) 2021 